\title{
OPTIMALISASI PERAN GEREJA KATOLIK DI BIDANG POLITIK: SEBUAH UPAYA PEMAKNAAN TAHUN POLITIK 2018 \\ DALAM MEWUJUDKAN BONUM COMMUNE
}

Oleh: Kristoforus Kopong

\begin{abstract}
Abstrak:
Tahun 1998 menjadi titik start Indonesia memasuki masa reformasi. Banyak agenda reformasi termasuk pembenahan di bidang politik. Namun sudah 20 tahun sejak masa reformasi praktik politik di Indonesia belum menunjukkan hakikatnya sebagai sarana untuk menata negara secara nasional dan konstitusional dalam suatu sistem untuk mencapai tujuan negara, yakni kebaikan umum atau "bonum commune" (keharmonisan, perdamaian, persekutuan dan kesejahteraan lahir dan batin dari setiap warga negara). Pemilihan umum sebagai pesta demokrasi (politik) tidak lebih sebagai ajang untuk memburu kursi kekuasaan. Karena itu politik oleh kebanyakan rakyat dipandang sebagai hal yang kotor. Memasuki tahun politik 2018, Gereja Katolik sebagai institusi sosial keagamaan yang juga ada di wilayah NKRI perlu terlibat dalam kehidupan konkrit umat manusia dan aktif memperjuangkan kesejahteraan umum sesuai dengan ketentuan yang berlaku. Dan salah satu sarana perjuangan adalah politik. Karena itu, dalam perspektif teologi pembebasan: politik dimaknai sebagai tanda dan sarana penyelamatan.
\end{abstract}

Kata-kata kunci: gereja, negara, politik, bonum commune

\section{Pengantar}

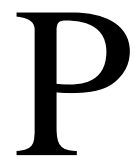

olitik pada hakekatnya merupakan sesuatu yang baik, untuk kebaikan umum. Namun justru secara faktual politik saat ini sudah dipenuhi dengan keburukan, penuh persaingan tidak sehat, pertentangan dan perpecahan, serta dijadikan sebagai alat untuk kepentingan diri sendiri atau kelompok. Kebaikan umum yang seharusnya diperjuangkan dan dijunjung tinggi, justru diabaikan dan dihancurkan. Hal seperti ini, biasanya menjadi sangat runyam dan terasa di saat-saat tensi bergerak naik terutama menjelang Pemilihan Umum entah itu pemilihan kepala daerah (pilkada) maupun pemilihan legislatif (pileg).

Sebagai institusi sosial-keagamaan, Gereja Katolik sangat prihatin dengan situasi yang terjadi selama ini.Lebih dari itu Gereja Katolik tidak hanya sampai pada merasa prihatin tetapi juga merasa peduli terhadap situasi yang demikian. Karena itu, Gereja Katolik merasa terpanggil untuk berpatisipasi dalam mencipatakan iklim politik yang aman dan nyaman di tanah air ini. Salah satu bentuk partisipasi Gereja Katolik dalam menciptakan iklim politik yang kondusif adalah dengan menyuarakan seruan profetis kenabiannya. 
Namun kondisi memperlihatkan bahwa seruan profetis Gereja Katolik selama ini ibarat menjaring angin, karena kontestasi politik sangat akrab dengansituasi persaingan, pertentangan bahkan perpecahan di tengah masyarakat.Sementara di level eksekutif maupun legislatif terpilihtidak menunjukkan itikad baik untuk mewujudkan kesejahteraan masyarakat. Para politisi yang sedang duduk di kursi eksekutif maupun legislatif kerap menggunakan kekuasaan bukan untuk mendatangkan kebaikan bersama (bonum commune), tetapi lebih untuk kepentingan diri, kelompok dan golongan. Politik hanya digunakan untuk sebangai sarana untuk mendapatkan kekuasaan, dan kekuasaan yang diperoleh hanya digunakan sebagai alat untuk mempertahankan kekuasaan pula.

Walaupun demikian Gerja Katolik tidak boleh lelah untuk tetap berperan aktif dalam bidang politik sebagai upaya evengelisasi baru yang melintasi batas dan memperluas horizon dalam mewujudkan bonum commune. Gereja Katolik tidak boleh diam, tetapi tetap menyerukan suara profetisnya sambil tetap mengupayakan cara dan strategi yang efektif untuk membentuk tatanan kehidupan bersama ke arah yang lebih baik. Hal ini tentu didasari oleh pemaknaan Gereja Katolik sebagai bagian dari pengalaman umat manusia akan kegembiraan, sukacita, harapan serta duka dan kecemasan sehari-hari, sebagaimana dirumuskan secara sangat baik dalam GS 1: "Kegembiraan dan harapan, duka dan kecemasan orang-orang zaman sekarang, terutama kaum miskin dan siapa saja yang menderita merupakan kegembiraan dan harapan, duka dan kecemasan para murid Kristus juga".

Pernyataan Konsili Vatikan II ini mereflesikan adanya keterbukaan luar biasa dari pihak Gereja Katolik terhadap kehidupan publik. Karena itu, Gereja Katolik perlu tampil membantu dan mendidik masyarakat supaya bisa mendefinisikan dirinya sendiri sebagai agen profetis dan pembaharu yang mampu membebaskan diri dari situasi yang dihadapi dengan kekuatan sendiri. Sehubungan dengan peran Gereja Katolik ini, ada suatu pernyataan yang cukup menohok kesadaran politik gereja, yaitu: "Jikalau umat Katolik tidak ikut terlibat dalam kehidupan politik atau ikut terlibat tetapi tidak menyuarakan dan menegakan moralitas dan spiritualitas Katolik maka, Gereja harus merasa diri gagal menjalankan misinya"(Cardinal O' Connor, 2005). Pernyataan ini merupakan tantangan sekaligus peluang dan spirit bagi Gereja Katolik sebagai institusi moral untuk tetap berperan dalam bidang politik sesuai dengan konstitusi dan ajaran gereja.

Tahun 2018 disebut tahun politik karena pada tahun ini (baca: 2018) diselenggarakan Pemilihan Kepala Daerah (pilkada) serentak di 171 daerah dan tahun 2019 akan berlangsung Pemilihan Legislatif (pileg) dan Pemilihan Presiden (pilpres). Gereja Katolik hendaknya memanfaatkan perhelatan politik itu sebagai kesempatan dan sekaligus lahan untuk melakukan upaya-upaya konkret dan kontekstual untuk mendorong percepatan pencapaian kesejahteraan masyarakat. Oleh karena itu, tulisan ini sesungguhnya ingin menantikan kembali Spirit Gereja Katolik agar dapat mengoptimalkan perannya di bidang politik guna mewujudkan bonum commune. 


\section{Napak Tilas Gereja Universal dalam Wilayah Politik}

Gereja Katolik sebagai sebuah institusi sosial-keagamaan memiliki sejarah panjang dalam percaturan ideologi-ideologi kenegaraan. Gereja Katolik boleh dikatakan tidak pernah alpa (baca: apolitis) dalam berkontribusi untuk menata kehidupan bersama dalam suatu bangsa dan negara. Namun sedikit berbeda dengan agama lain terutama Islam yang sejak nabi Muhammad hijrah ke Medinah berhadapan dengan tugas untuk membangun sebuah komunitas dan mempertahankannya terhadap serangan-serangan dari dalam dan luar, Gereja dalam abadabad pertama tidak terlibat dalam hal kekuasaan (meskipun tidak jarang ada pegawai tinggi istana Kaisar Romawi yang Kristen). Gereja pada awal mula terdiri atas orang-orang yang ada di bawah mereka yang berkuasa. Sikap Gereja terhadap penguasa dunia dalam Perjanjian Baru sangat jelas. Di satu pihak Gereja mengakui wewenang pemerintah, menegaskan kewajiban umat untuk taat kepada negara dan menjadi warga negara yang positif (bdk. Rum. 13: 1-7; 1 Ptr 2: 13). Namun, sekaligus Gereja berpegang teguh pada apa yang dikatakan Petrus kepada para pemimpin Yahudi, "Kita harus lebih taat kepada Allah daripada kepada manusia" (Kis. 5:29).

Jadi Gereja pada dasarnya taat kepada pemerintah, kecuali tuntutan kehendak pemerintah bertentangan dengan kehendak Allah dan moralitas universal. Tentang hal ini sejarah Gereja mencatat bahwa walaupun umat Kristen selalu menjadi warga yang baik dan tidak pernah memberontak, namun tidak sedikit umat yang terbunuh demi mempertahankan imannya. Alasannya, mereka menolak menyembah kaisar sebagai dewa dan tidak menghaturkan persembahan kepadanya. Bagi Gereja secara khusus mereka yang terbunuh (baca martir) tidak boleh ada kekuasaan di dunia yang didewakan. Dan ini justru tidak disukai oleh kebanyakan penguasa dunia (bdk. Suseno, 2004:176).

Pada abad ke-4 situasi itu berubah terutama ketika Kaisar Konstantin memberikan kebebasan beragama kepada orang-orang Kristen. Bersamaan dengan itu orang Kristen pun diberi peran untuk menangani hal-hal yang berkaitan dengan kekuasaan. Namun momentum ini kemudian menimbulkan persoalan serius di Gereja Timur dimana Kaisar Yunani dan kemudian Tsar Rusia yang seakan-akan menjadi kepala Gereja. Artinya, kekuasaan duniawi/manusiawi dicampuradukan dengan kekuasaan adiduniawi/ilahi. Tidak demikian halnya dengan Gereja Kristen Romawi yang tetap teguh pada prinsipnya bahwa tidak boleh ada sebuah negara/kerajaan di dunia ini yang dipandang sebagai penjelmaan Kerajaan Allah.

Prinsip Gereja Kristen Romawi tersebut dipertegas kembali pada Abad Pertengahan oleh Thomas Aquinas. Menurutnya wewenang negara tidak bisa tanpa batas: dasar wewenang negara adalah hukum kodrat dan hukum kodrat sendiri itu adalah hukum abadi Allah sendiri. Karena itu, wewenang negara akan berakhir jika negara memerintahkan sesuatu yang bertentangan dengan hukum kodrat (kehendak Allah dan moralitas). Legitimasi kekuasaan negara ada sejauh negara tidak menjadi negara kekuasaan (machtstaat). Konflik antara kekuasaan Kaisar dan kekuasaan Paus pada masa itu merupakan momentum penting dan bersejarah bagi para teolog dan ahli hukum untuk menegaskan koridor kekuasaan masing-masingnya. Dari situ Gereja Latin semakin menyadari bahwa kekuasaan duniawi (negara dan kerajaan) secara hakiki ada tetapi terbatas dan 
apabila kekuasaan tersebut melampaui batasnya, maka umat berhak dan kadang-kadang berkewajiban untuk melawan (bdk. Suseno, 2004:177).

Pada abad ke-16, dengan Reformasi Protestan, Kesatuan Gereja Barat pecah. Hubungan Gereja-gereja Protestan dengan negara berbeda polanya dengan Gereja Katolik. Gereja-gereja Luteran memilih untuk "merapat ke wilayah kekuasaan" dengan mengangkat pangeran setempat menjadi kepala Gereja lokal masing-masing (menggantikan Paus dan Uskup) dengan akibatnya gereja Luteran selama empat abad menjadi sangat taat terhadap negara. Sementara Gereja Katolik terutama para teolog di satu pihak mendukung kekuasaan terbatas raja-raja-sesuai dengan ajaran Thomas Aquinas tetapi mereka, terutama teolog Skolastik Yesuit sangat berkontribusi dalam perkembangan hukum internasional yang kemudian akan menjelma dalam paham hak asasi.

Keterlibatan Gereja Katolik dalam refleksi kenegaraan mengalami kemunduran selama abad ke-18 dan ke-19. Pada dua abad ini Gereja Katolik berada dalam krisis dan seakan-akan kehilangan kontak dengan zamannya. Dua faktor yang menyebabkan krisis, yaituadanya serangan dari filosof pencerahan dan Revolusi Perancis yang menyebabkan warga Gereja (imam, rohaniwan, dan suster) terbunuh. Kondisi ini baru mulai pulih apada abad ke-20 terutama ketika Gereja berhadapan dengan ekses-ekses kapitalisme. Gereja mulai memformulasikan suatu ajaran mendasar tentang keadilan sosial dan martabat manusia pekerja yang menempatkan Gereja di garis depan kekuatan yang menuntut reformasi sistem perekonomian kapitalis. Bersamaan dengan itu awam-awam Katolik mulai menyadari bahwa pola kenegaraan pasca-Revolusi Perancis yang demokratis justru membuka pintu bagi umat Katolik untuk kembali berpartisipasidalam kehidupan nasional.

\section{Peran Gereja Katolik Indonesia dalam Bidang Politik}

Secara historis berkembangnya wacana politik di dunia Barat sangat dipengaruhi oleh para filosof Yunani Kuno, seperti Plato dan Aristoteles. Kedua filosof ini meletakan politik dalam hubungannya dengan apa yang bersentuhan dengan pemerintahan negara (politicos), bagaimana mengelola dan menyelenggarakan kebijakan-kebijakan dalam kehidupan bernegara. Lebih jauh, politik dikaitkan dengan "mekanisme pemerintahan" dalam mengatur relasi kelompok-kelompok sosial yang bersentuhan langsung dengan urusan penggunaan kekuasaan. Karena itu, secara implisit politik berkaitan dengan etika (moral); sebab ia berurusan dengan perkara manusia dan kemanusiaannya (kebahagiaan dan kesejahteraannya) dalam suatu negara (bdk. Regus, 2004: 76).

Maksud (tujuan dan sasaran) politik sama dengan etika yang mengacu kepada tujuan hidup manusia, yaitu mencapai apa yang diistilahkan Sokrates dengan "eudaimonia" (kebahagiaan sejati manusia). Jadi, mereka menganggappolitik sebagai usaha mencapai masyarakat terbaik (negara), di mana manusia bisa hidup bahagia karena memiliki peluang untuk mengembangkan kemampuan alamiah (potensialitas manusia) dalam kehangatan moralitas dan 
solidaritas yang sehat. Dalam bahasa H. Arendt (1958:126), setiap kegiatan politik yang berlangsung di ruang publikitu adalah suatu usaha untuk "menyelesaikan segala perkara melalui kata-kata dan persuasi (argument untuk meyakinkan pihak lain),dan bukan melalui kekuatan dan kekerasan". Politik adalah suatu kegiatan sintesis: mengubah benturan niat menjadi langkah kerja sama dengan menunjukkan butir-butir yang saling menguntungkan bagi kedua belah pihak. Di sinilah letak politik sebagai seni, seni untuk menjembatani pelbagai kebutuhan dan kepentingan individual menjadi kepentingan bersama.

Dewasa ini, wacana politik telah mengembara jauh ke dalam peradaban manusia. Politisi, ilmuwan politik, birokrat dan para penguasa telah menerjemahkan politik dalam keanekaan wajah dengan beragam penekanan dan dalam kerangka kepentingan kelompok dan pribadinya masing-masing. Subjektivitas pemaknaan politik ke dalam ruang kepentingan kelompok atau individual (baca:penguasa) berdampak pada pengambilan kebijakan politik yang menyimpang bahkan tidak jarang bertentangan dengan kebaikan umum (bonum commune)yang menjadi "kunci" latar belakang aktivitas politik itu sendiri.

Subjektivisme politik sebagaimana diuraikan di atas cukup mewarnai peta politik di Indonesia mulai dari masa Orde Lama, Orde Baru, dan masa Reformasi. Subjektivisme politik yang berlangsung secara massif dari waktu ke waktu pada setiap masa kekuasaan politik mengakibatkan kekuasaan itu cenderung mutlak dan merusak sacara mutlak pula. Subjektivisme politik yang terjadi pada masa Orde Lama telah menciptakan "tragedi politik" yang amat sangat memilukan. Peristiwa G30/S PKI menjadi warna dasar dari tragedi politik masa itu. Tampuk kekuasaan yang kemudian berpindah dari Soekarno kepada Soeharto (Orde Baru)bukanlah menjadi akhir tragedi politik di Indonesia. Justru pada masa Orde Baru ini, subjektivisme politik penguasa terasa semakin kental dan "beranak pinang" hingga 32 tahun. Masa pemerintahan (baca: presiden) yang tidak dibatasi secara tegas oleh konstitusi telah menimbulkan "tragedi politik" yang panjang dan sangat memprihatinkan. Pada masa itu Indonesia mengalami krisis yang hampir sempurna dalam setiap bidang kehidupan. Krisis ini berpuncak tahun 1997 yang kemudian menumbangkan kekuasaan rezim Orde Baru.

Gereja Katolik di Indonesia setelah Konsili Vatikan II tidak mundur dari komitmenya terhadap politik. Mengikuti amanat Yesus, Gereja terus berupaya melakukan pengijilan secara integral dan mengena berdasarkan situasi, persoalan dan kebutuhan lokal Indonesia. Keterlibatan politik terwujud dalam tindakan profetis, etis dan praktis membangun tata dunia Indonesia berdasar nilai-nilai Injili seperti cinta kasih, kedamaian, keadilan, pelayanan dan kesejahteraan bersama. Gereja terus berdialog dengan semua golongan dan lapisan masyarakat Indonesia yang begitu plural dalam rangka merealisir konsep Indonesia sebagai satu rumah bersama yang adil dan sejahtera. Gereja katolik Indonesia terus mendefiniskan dirinya sebagai "rumah Tuhan tanpa dinding" serta institusi sosial yang terus berbela rasa, mewartakan pengharapan dan pertobatan serta menciptakan masyarakat baru Indonesia yang lebih manusiawi dan berkeadilan. 


\section{Optimalisasi Peran Gereja Katolik dalam Perhelatan Tahun Politik 2018}

Suhu politik mulai memanas saat Pilkada serentak 2018 dan akan tambah panas menjelang Pilpres dan Pileg 2019. Bahkan pada tahun 2018 sampe 2019 suhu politik akan meningkat secara merata di seluruh wilayah tanah air. Ramalan ini mulai terbukti pada resultante politik hukum negara dimana tahun 2018 diselenggarakan Pemilihan Kepala Daerah (pilkada) serentak di 171 daerah dan berlanjut tahun 2019 dengan Pemilihan Legislatif (pileg) dan Pemilihan Presiden (pilpres).

Meningkatnya suhu politik dalam perhelatan akbar ini mulai terasa sejak awal Januari 2018 lalu. Hal ini di ditandai dengan adanya peningkatan hubungan solidaritas dan rasa kesetiakawanan yang didasarkan pada kepentingan politik. Di samping itu mulai terbentuknya pola-pola untuk menarik simpati masyarakat yang dilakukan oleh elit politik, cenderung menjadikan masyarakat sebagai objek dari pada sebagai subjek. Implikasinya dalam kehidupan politik, yang tumbuh dan berkembang adalah partisipasi politik yang dimobilisasi dan bukan oleh partisipasi politik yang otonom, yang tumbuh atas kesadaran yang rasional masyarakat akar rumput.

Dampak dari distorsi kesadaran politik masyarakat oleh para elite politik tersebut adalah pertama, pada tataran pemilih; menumpulnya kesadaran politik masyarakat pemilih. Rasionalitas para pemilih tereliminasi oleh mobilisasi para elit politik mulai dari partai politik, para calon/kandidat dan tim sukses di lapangan. Kampanye hitam dan politik uang cenderung digunakan oleh para elite politik sebagai strategi jitu untuk mendulang suara. Para pemilih kemudian memberikan hak suaranya bukan berdasarkan hati nuraninya melainkan berdasarkan kepentinga para elite politik. Itu berarti masyarakat pemilih tidak didik untuk menggunakan hak suaranya sebagai bentuk tanggung jawab moralnya untuk menata kehidupan bersama. Suara hati dan nurani pemilih sebagai benteng moralitas terkubur oleh kepentingan sesaat para elit politik. Hal ini lambat laun akan menjadi budaya politik akar rumput yang justru meredusir makna perhelatan politik sebagai "seni" untuk menata pemerintahan dan negara mewujudkan kebaikan bersama (bonum commune).

Kedua, pada tataran elite (seperti partai politik, para calon/kandidat dan tim sukses di lapangan). Mekanisme dan proses politik yang tidak rasional dan jauh dari tuntutan moral akan menghasilkan pemerintah baik itu eksekutif (kepala daerah dan presiden) maupun legislatif (daerah dan pusat) yang tidak memiliki integritas dan kredibilitas. Pemimpin yang seperti ini akan lebih menggunakan kekuasan untuk mempertahankan kekuasaan daripada untuk melayani masyarakat melalui penataan pemerintaah dan negara untuk mewujudkan kebaikan bersama (bonum commune). Baginya dalam politik praktis, kawan dan lawan tidak ada yang abadi, satusatunya yang abadi adalah kepentingan (kekuasaan).

Dampak akhir dari semua itu adalah bonum commune sebagai tujuan akhir proses politik dan tujuan negara tidak terwujud. Dalam Pembukaan UUD Negara Republik Indonesia Tahun 1945 khususnya alinea IV tertuang tujuan negara yang berbunyi: 
Kemudian daripada itu untuk membentuk suatu pemerintah Negara Indonesia yang melindungi segenap bangsa Indonesia dan seluruh tumpah darah Indonesia dan untuk memajukan kesejahteraan umum, mencerdaskan kehidupan bangsa, dan ikut melaksanakan ketertiban dunia yang berdasarkan kemerdekaan, perdamaian abadi dan keadilan sosial ...

Ketika konteks sosial bangsa saat ini dikonfrontir dengan tujuan hidup berbangsa dan bernegara, maka akan tampak bahwa kesejahteraan yang menjadi kebaikan bersama (bonum commune) masih jauh dari harapan. Kemiskinan dan pengangguran menjadi masalah klasik yang tidak pernah terselesaikan. Sementara itu muncul pula masalah-masalah global seperti terorisme, narkoba, dan human trafficking serta masalah korupsi yang dilakukan oleh pejabat negara yang belakangan marak diberitakan.

Pada titik ini Gereja Katolik perlu mengoptimalkan perannya dalam bidang politik;terutama di dalam perhelatan Tahun Politik 2018 dan 2019. Optimalisasi peran Gereja Katolik, antara lain: pertama, Gereja Katolik perlu memandang politik sebagai salah satu bidang pelayanan demi perwujudan kasih Allah. Sadar akan politik sebagai pelayanan serta perwujudan kasih Allah itu maka, keterlibatan umat dalam kehidupan sosial-politik terus menjadi sebuah komitmen kolektif. Alasan mendasar yang membuat umat Katolik terus terlibat aktif dalam urusan politik terletak pada panggilan Ilahi untuk mempertegas moral politik yang benar yaitu politik demi keadilan, perdamaian, kesejahteraan dan kebaikan bersama serta penghormatan terhadap hak-hak asasi dan martabat manusia (CBCP, 2005; CBCP, 2002; Pope John Paul II. 1998). Sehubungan dengan itu Yakobus 4:17 berkata: "Jadi jika seseorang tahu bagaimana ia harus berbuat baik, tetapi ia tidak melakukannya, ia berdosa".

Cara pandang di atas dapat membantu Gereja Katolik untuk menjadikan politik secara khusus Tahun Politik (2018/2019) sebagai salah satu sarana dan sekaligus momentum yang tepat untuk memperjuangkan kesejahteraan seluruh rakyat. Dalam arti tertentu politik (baca: Tahun Politik 2018/2019) menjadi tanda dan sarana penyelamatan atau dalam bahasa Kristiyanto (2008) disebut sakramen politik. Hal ini memang tidak mudah ketika ruang politik telah lama dijadikan sebagai arena perebutan kekuasaan, pangkat, dan harta semata. Namun bukan berarti hal itu tidak bisa, jika semua warga gereja memiliki kesadaran dan kedewasaan (budaya) politik yang matang. Budaya politik yang matang tampak pada pemahaman yang benar bahwa politik adalah medan kehidupan publik, dunia bersama, yang mampu menggabungkan manusia hingga mereka tidak saling menerkam satu sama lain, melainkan bekerja sama demi kepentingan umum.

Kedua, Gereja Katolik sebagai institusi yang telibat dalam urusan sosial kemasyarakatan perlu memberikan pendidikan politik etis kepada masyarakat akar rumput. Pendidikan politik etis bukan bertujuan untuk memobilisasi massa (ad captandum vultus) secara langsung maupun tidak langsung untuk mendukung ataupun tidak mendukung kelompok (partai) tertentu. Tapi tujuan pendidikan politik adalah untuk membentuk kepribadian politik, membangun kesadaran politik, dan meningkatkan partisipasi politik (Kopong, 2015: 215-216). Artinya, pendidikan politik tidak hanya bertujuan membangun dan mengembangkan pengetahuan politik tertentu, seperti sistem pemilu, sistem kepartaian, dan demokrasi, melainkan juga membentuk dan mengembangkan 
orientasi-orientasi yang meliputi nilai-nilai, arah dan perasaan politik. Nilai-nilai merupakan fatsun politik yang menjadi parameter pengontrol perilaku penguasa (politisi). Sedangkan keyakinan merupakan spirit yang menggerakan orang untuk melakukan atau memperjuangkan kesejahteraan umum dan kebaikan bersama.

Ketiga, Gereja Katolik sebagai institusi sosial-keagamaan yang selalu berpihak kepada kebaikan banyak orang terutama orang-orang kecil perlu berperan secara nyata dan konkrit untuk ambil bagian dalam proses politik di tahun 2018/2019. Gereja Katolik secara cerdas dan bijak perlu berusaha untuk menata politik sesuai dengan batas tugas dan cakupan kewenangannya; sehingga tahun poltik 2018/2019 benar-benar dimaknai sebagai sikuit kehendak yang menjembatani kepentingan individual yang majemuk itu hingga terwujud suatu "ruang publik" yang memepertemukan aneka ragam kepentingan serta kebutuhan individual yang berbeda itu. Jan Riberu (2008) berpendapat bahwa umat Katolik perlu menjadi instrumen cinta, perdamaian dan persahabatan di tengah masyarakat Indonesia yang majemuk. Karena nasib dan hidup masyarakat Indonesia ditentukan dan diukur oleh apa yang kita lakukan bagi sesama (Mat.25:3540), terutama yang kecil, lemah dan terpinggirkan (Luk.4:18) (KWI: Tanggung Jawab Gereja Katolik, 2009).

Kehadiran warga Gereja dalam struktur dan tatanan sosial masyarakat yang mejemuk merupakan garam dan terang bagi sesama sesuai tugas tanggungjawab, situasi dan kemampuannya masing-masing, serta sesuai aturan yang berlaku. Dalam hal ini semua anggota Gereja Katolik dikelompokkan dalam tiga komponen, yaitu : kaum klerus, biarawan-biarawati dan kaum awam. Semua komponen dapat dan perlu memainkan peranannya sesuai hak dan kewajibannya sebagai warga masyarakat/negara dan serentak warga Gereja. Selain itu secara khusus kaum klerus serta biarawan dan biarawati berperan secara formatif dan tak langsung, sebagai pembina, pengawal dan pengontrol. Artinya, peran mereka lebih pada ranah politik etis: pendampingan (advocacy), pemberdayaan (empowerment) dan solidaritas (solidarity) dengan meneladani Yesus Kristus.

Teknik berpolitik ini sebagaimana dimaksudkan di atas telah dilakukan sejumlah tokoh Katolik seperti Mgr. Soegijapranata, Kardinal Darmoyuwono, Rm. Mangunwijaya, Frans Seda, Kasimo, dll. Politik tidak beorientasi merebut kekuasaan atau pemerintahan, tetapi politik moral (etik). Politik yang memperjuangkan tegaknya nilai-nilai keadilan, kebenaran, kesejahteraan, dan kemajuan peradaban dalam masyarakat. Sedangkan kaum awam berperan secara praktis dan langsung, sebagai politisi, pemimpin eksekutif dan birokrat. Kelompok ini dalam berpolitik hendaknya berpedoman pada kearifan antik yang sudah teruji, dan sering diajukan oleh Bapak Uskup Pahlawan Nasional RI, Mgr. Albertus Soegijapranata (alm.), yaitu In Principiis Unitas (dalam hal prinsip/asas/esensi-PERSATUAN); In Dubiis Libertas (dalam hal-hal yang masih terbuka-KEBEBASAN; dan In Omnibus Caritas (dalam segala hal-KASIH). 
Keempat, Gereja Katolik sebagai institusi keagamaan perlu juga proaktif melakukan pemurnian ('purifikasi') praktik politik yang cenderung kotor, manipulatif, dan tidak beretika. Suara profetis (kenabian) perlu digemakan di tahun politik (2018/2019) terutama dalam ruangruang politik yang sudah terlanjur kotor, licik, dan penuh tipu muslihat. Peran suara profetis (kenabian) dalam bidang politik adalah menyerukan pertobatan, mengeritik kepalsuan dan penindasan dan menyuarakan kepentingan mereka yang dibungkam suaranya. Gereja berperan sebagai institusi yang "menguduskan" politik dan politisinya. Dalam arti tertentu Gereja sejati harus mengupayakan agar surga dan bumi itu menyatu dalam harmoni yang indah karena itulah doa yang Yesus ajarkan, yang juga merupakan antisipasi terhadap realitas eskatologis yang akan kita nikmati kelak.

Khusus bagi politisi Katolik, St. Thomas More, pelindung para negarawan dan politisi Katolik mengingatkan bahwa "Politik tidak bisa dipisahkan dari moralitas." Seorang politikus yang profesional adalah seorang yang cakap membawa aspirasi masyarakat dengan isu-isu yang mencuat ke permukaan yang perlu dipecahkan ke arena politik dengan menggunakan etika politik. Lebih lanjut Kitab Suci menegaskan, "Usahakanlah kesejahteraan kota ke mana kamu aku buang, dan berdoalah untuk kota itu kepada Tuhan sebab kesejahteraannya adalah kesejahteraanmu" (bdk.Yeremia 29:7). Karena itu politik merupakan hak, tanggungjawab dan panggilan semua anggota Gereja termasuk politisi Katolik.

Peran-peran politik di atas, menunjukkan bahwa Gereja terpanggil untuk merumuskan suatu eklesiologi baru dimana Gereja tidak lagi dilihat sebagai suatu institusi sosial yang terisolir melainkan bagian integral dari pengalaman hidup umat beriman dan masyarakat umumnya. Artinya, Gereja Katolik Indonesia terus mendefiniskan dirinya sebagai "rumah Tuhan tanpa dinding" serta institusi sosial yang terus berbela rasa, mewartakan pengharapan dan pertobatan serta menciptakan masyarakat baru Indonesia yang lebih manusiawi dan berkeadilan. Selanjutnya, Gereja juga terus mendukung dan mendorong kaum awam katolik yang berkualitas dan berintegritas agar lebih berani mengambil peran-peran sosial dan politik sebagai lahan pewartaan Kabar Gembira dan menghidupi nilai-nilai Pancasila.

\section{Penutup}

Cita-cita luhur bangsa Indonesia telah digariskan oleh para pendiri negara, seperti dicantumkan dalam alinea kedua Pembukaan Undang-Undang Dasar Negara Republik Indonesia Tahun 1945, sebagai berikut: "Dan perjuangan pergerakan kemerdekaan Indonesia telah sampailah kepada saat yang berbahagia dengan selamat sentausa mengantarkan rakyat Indonesia ke depan pintu gerbang kemerdekaan Negara Indonesia yang merdeka, bersatu, berdaulat, adil dan makmur."

Politik merupakan sarana bersama untuk mencapai cita-cita luhur bangsa dan negara. Karena pada prinsipnya, politik merupakan seni memanage (the art of managing), seni mengurus atau merawat bangsa dan negara dalam kaitannya dengan tanggungjawab untuk melayani rakyat. 
Di sini politik menyiratkan kebijakan terorganisasi yang diperlukan untuk mencapai tujuan hidup bersama, yakni bonum commune (kebaikan bersama) yang adil dan merata (bdk. Kristiyanto, 2008).

Namun ketika politik sebagai sarana kemaslahatan manusia Indonesia disalahgunakan oleh kelompok tertentu untuk kepentingannya sendiri dan menindas rakyat kebanyakan, serta memecah-belahkan bangsa dan negara, maka Gereja Katolik sebagai institusi social-keagamaan perlu menyerukan suara profetis kenabiannya. Dimensi etis (moral) suara profetis kenabian terhadap praktik politik yang menyimpang dari hakikatnya perlu lebih jelas dan tegas sehingga tidak menimbulkan kesan bahwa Gereja Katolik sedang "mengerejanisasi politik" ataupun sebaliknya politik yang menyimpang itu sedang "mempolitisasi gereja". Tapi sebagai jawaban atas panggilan Ilahi untuk menjadikan politik sebagai tanda dan saran keselamatan bagi bangsa dan negara.

\section{Kepustakaan:}

Arendt, Hannah. The Human Condition. University of Chicago Press, 1958.

Hardawiryana, R. (penterj.) Dokumen Konsili Vatikan II. Jakarta: Obor, 1993.

KWI,Tanggung Jawab Gereja Katolik, 2009.

Kopong, Kristoforus. Membumikan Pancasila Mengurai Benang Kusut NKRI. Yogyakarta: WR, 2015.

Kristiyanto, Eddy. Sakramen Politik: Mempertanggungjawabkan Memoria. Yogyakarta: Lamalera, 2008.

O’ Connor, The Hidden Manna A Theoloy of the Eucharist, Secon Edition, 2005.

Regus, Sketsa Nurani Anak Bangsa. Jakarta: Obor, 2004.

Riberu, J. Awam dalam Tata Dunia, Renungan Penyegaran dan Penataran Awam Katolik Indonesia. Ditjen Bimas Katolik, 2008.

Suseno, Franz Magnis. Menjadi Saksi Kristus di Tengah Masyarakat Majemuk. Jakarta: Obor, 2004.

UUD Negara Republik Indonesia Tahun 1945 